\title{
ASSESSMENT OF PRETREATMENT TO MICROFILTRATION FOR DISALINATION IN TERMS OF FOULING INDEX AND MOLECULAR WEIGHT DISTRIBUTION
}

\author{
K. Chinu*; A. H. Johir*; S. Vigneswaran*1; H. K. Shon *; Jaya Kandasamy* \\ * Faculty of Eng., University of Technology, Sydney, P.O. Box 123 Broadway, NSW 2007, \\ Australia \\ ${ }^{1}$ corresponding author: S. Vigneswarna \\ Tel.+61(2) 9514 2641; Fax +61(2) 95142633 email: vigid@eng.uts.edu.au
}

\begin{abstract}
In this study, different processes such as flocculation with ferric chloride $\left(\mathrm{FeCl}_{3}\right)$ and deep bed filtration (sand filtration and dual media filtration) as a pre-treatment to microfiltration (MF) were used for seawater desalination. The performance of these pre-treatments was determined in terms of silt density index (SDI) and modified fouling index (MFI) and flux decline in MF. Flux declin of MF with seawater was $45 \%$ without any pre-treatment, $42 \%$ after pre-treatment of $\mathrm{FeCl}_{3}$ flocculation, 24\% after pre-treatment of sand filtration with inline coagulation and 22\% after pre-treatment of dual media filtration (sand and anthracite), respectively. MFI and SDI also indicated that deep bed filtration with in- line flocculation was better pre-treatment than flocculation alone. Detailed molecular weight distribution (MWD) of seawater organic matter was examined after different pretreatments. MWD of the initial seawater mainly ranged from 1510 Da to $130 \mathrm{Da}$. Deep bed filtration with in-line flocculation removed relatively large molecular weight of organic matter $(1510-1180 \mathrm{Da})$, while the small molecular weights (less than $530 \mathrm{Da}$ ) were not removed.
\end{abstract}

Keywords: Pre-treatment, Fouling index, Flux decline, Molecular weight distribution.

\section{Introduction}

The growth in membrane applications for desalination has been exponential over the last decade and is expected to continue as per capita water requirements increase and populations multiply. Recent advances in membrane technology have led to broad application, and reverse osmosis (RO) systems now represent the fastest growing segment of the desalination market. Nevertheless the operation of membrane-based desalination plants still remains complex mainly due to membrane fouling. Membrane fouling can be classified as particulate/colloidal or organic fouling. Both particulate/colloidal and organic fouling can be controlled by pretreatment. As a result, good pre-treatment of seawater can provide good quality of feed water for the RO desalination plant. Moreover, it will reduce the fouling for RO membrane and reduce the energy requirements.

Deep bed filtration is widely used to RO desalination plant. However, this pre-treatment is not effective for the variable feed water but still accepted as a satisfactory pre-treatment. Recently 
low pressure membrane based on filtration technologies has become attractive as pretreatment to RO desalination. Both ultrafiltration (UF) and microfiltration (MF) pre treatments are suitable for industrial-scale applications of RO. Wolf et al. [1] compared UF with conventional pre-treatment (in-line coagulation and 2 stage sand filters) for seawater. They measured silt density index $\left(\mathrm{SDI}_{15}\right)$ and it was found to be lower than 2.5 for UF but greater than 4 for conventional pre-treatment. Treated water quality was consistent for UF but fluctuating for conventional pre-treatment. UF is a positive barrier to particles and pathogens but conventional pre-treatment is not a positive barrier for colloidal and suspended solids[1]. Brehant et al. [2] compared UF/MF with conventional filtration for surface seawater $\left(\mathrm{SDI}_{15}\right.$ $\sim 13-25$ ). They found out with conventional filtration (dual media filtration) that SDI does not reduce below 2.5. SDI was reduced to 1 with $\mathrm{UF}$ (UF+ $1 \mathrm{mg} / \mathrm{l} \mathrm{FeCl} \mathrm{l}_{3}$ dose). UF as pretreatment with inline coagulation of $1 \mathrm{mg} / \mathrm{I} \mathrm{FeCl}_{3}$ reduces the RO fouling and RO plant cost [2]. Pearce [3] from their study with waste and brakish water observed that UF/MF pretreatment ensures higher RO flux, less fouling, chemical dose reduction and better on-stream time.

The objectives of this study were to investigate deep bed filtration (sand and dual media filtration) as pre-treatment to MF in terms of flux decline. The performance of different pretreatments was investigated in terms of $\mathrm{SDI}_{15}$, MFI and moleculare weight distribution (MWD) of organic matter.

\section{Materials and methods}

\subsection{Seawater}

The experiments were conducted on-site at Chowder Bay, Sydney, Australia. Seawater was pumped from $1 \mathrm{~m}$ below the sea surface level and filtered using a centrifuge filtration system to remove the large particles. The filtered seawater had the following characteristics.

Table1: Characteristics of seawater used in this study

\begin{tabular}{|c|c|c|c|}
\hline Analysis category & Concentration & Analysis category & Concentration \\
\hline $\mathrm{pH}$ & 8.2 & $\mathrm{NO}_{2}-\mathrm{N}(\mathrm{mg} / \mathrm{L})$ & $<0.01$ \\
\hline Salinity (g/L) & $37-40$ & Se $(\mu \mathrm{g} / \mathrm{L})$ & $<25$ \\
\hline $\begin{array}{c}\text { Conductivity } \\
\text { (ms/cm) }\end{array}$ & $51.8-55.5$ & $\operatorname{Cr}(\mu g / L)$ & $<25$ \\
\hline $\mathrm{TSS}^{*}(\mathrm{mg} / \mathrm{L})$ & $2-13$ & Fe (mg/L) & $<0.05$ \\
\hline Turbidity (NTU) & $0.5-0.7$ & $\mathrm{Mn}(\mu \mathrm{g} / \mathrm{L})$ & $2-3$ \\
\hline $\begin{array}{c}\text { Alkalinity (mg/L as } \\
\left.\mathrm{CaCO}_{3}\right)\end{array}$ & $\begin{array}{c}\text { 66-80 (mostly } \\
\text { bicarbonate) }\end{array}$ & $\mathrm{Ni}(\mu \mathrm{g} / \mathrm{L})$ & $<10$ \\
\hline $\mathrm{UV}_{254}$ & 0.026 & $\mathrm{Cu}(\mu \mathrm{g} / \mathrm{L})$ & $<10$ \\
\hline $\mathrm{DOC}^{* *}(\mathrm{mg} / \mathrm{L})$ & $<1$ & $\mathrm{~Pb}(\mu \mathrm{g} / \mathrm{L})$ & $<2$ \\
\hline BOD (mg/L) & $<1$ & As $(\mu \mathrm{g} / \mathrm{L})$ & $<25$ \\
\hline Coliforms/100mL & $<2$ & $\mathrm{Cd}(\mu \mathrm{g} / \mathrm{L})$ & $<0.1$ \\
\hline $\begin{array}{c}\text { Total phosphorus } \\
\text { (mg/L) }\end{array}$ & $<0.01-0.06$ & $\mathrm{Hg}(\mu \mathrm{g} / \mathrm{L})$ & $<1$ \\
\hline $\mathrm{NO}_{3}-\mathrm{N}(\mathrm{mg} / \mathrm{L})$ & 0.01 & $\mathrm{Zn}(\mathrm{mg} / \mathrm{L})$ & $<25$ \\
\hline $\mathrm{NH}_{4}-\mathrm{N}(\mathrm{mg} / \mathrm{L})$ & 0.02 & & \\
\hline
\end{tabular}

* Total suspended solids, ${ }^{* *}$ Dissolved organic carbon 


\subsection{Deep bed filtration Pre-treatment}

In this study, the following pre-treatment methods were used.

i) Flocculation followed by microfiltration

Flocculation was carried with ferric chloride $\left(\mathrm{FeCl}_{3}\right)$, at a dose of $1 \mathrm{mg} / \mathrm{L}$. The flocculant together with the collected seawater was stirred for $1 \mathrm{~min}$ at $100 \mathrm{rpm}$ followed by slow mixing for $20 \mathrm{~min}$ at $30 \mathrm{rpm}$. The supernatant was collected to determine the SDI, MFI, MWD and flux decline with a MF membrane.

ii) Deep bed filtration followed by microfiltration

Sand and dual media (sand and anthracite) filtrations were used as media for depth bed filters. The filter depth was kept at $80 \mathrm{~cm}$ for both the sand filter and the dual media filter. The velocity of the effluent was maintained at $10 \mathrm{~m} / \mathrm{h}$. Both media filters were operated for 6 hrs. The effluent was collected when turbidity removal became constant. Ferric chloride $\left(\mathrm{FeCl}_{3}\right)$ of $1 \mathrm{mg} / \mathrm{L}$ was used as inline coagulant.

\subsection{SDI and MFI}

Silt Density Index (SDI) and Modified Fouling index (MFI) were measured after each pretreatment. SDI is the most common fouling index used in the industry. The SDI procedure is described in the American standard testing and methods (ASTM) D4189-95. SDI is a simple correlation of variation in filtration time of a known volume of the feed after a certain period of filtration time (usually 15 minutes). The SDI is calculated from the following equation

$$
S D I_{15}=\frac{1-\left(t_{i} / t_{f}\right)}{T_{t}} \times 100
$$

Equation $\quad 1$

Where

$\mathrm{t}_{\mathrm{i}}=$ Initial filtration time (to filter a fixed volume of $500 \mathrm{~mL}$ )

$\mathrm{t}_{\mathrm{f}}=$ Final filtration time (to filter the same fixed volume of $500 \mathrm{~mL}$ )

$\mathrm{T}_{\mathrm{f}}=$ Elapsed time

MFI is an extension of SDI and was developed by Schippers in 1980 [4, 5]. The MFI is determined from the gradient of the general cake filtration equation at constant pressure by plotting $\mathrm{t} / \mathrm{V}$ versus $\mathrm{V}[6]$.

$$
\frac{t}{V}=\frac{\eta R_{m}}{\Delta P A}+\underset{\text { MFI }}{\stackrel{\frac{\eta \alpha C_{b}}{2 \Delta P A^{2}}}{\longrightarrow}} V
$$

Equation 2

Where,

$\mathrm{V}$ = total permeate volume (l)

$\mathrm{R}_{\mathrm{m}}=$ membrane resistance

$\mathrm{t}=$ filtration time (s)

$\Delta \mathrm{P}=$ applied trans-membrane pressure $(\mathrm{Pa})$

$\eta=$ water viscosity at $20^{\circ} \mathrm{C}\left(\mathrm{N} \mathrm{s} / \mathrm{m}^{2}\right)$

$\alpha=$ the specific resistance of the cake deposited 
$\mathrm{C}_{\mathrm{b}}=$ the concentration of particles in a feed water (mg/l)

$\mathrm{A}=$ the membrane surface area $\left(\mathrm{m}^{2}\right)$.

MFI is defined as the gradient of this linear region of $t / \mathrm{V}$ vs. $\mathrm{V}$ plot normalized to standard reference values of $207 \pm 3 \mathrm{kPa}$ transmembrane pressure, a feed water temperature of $20^{\circ} \mathrm{C}$ and MF with a surface area of $47 \mathrm{~mm}$ diameter and a pore size of $0.45 \mu \mathrm{m}$.

\subsection{Molecular weight distribution (MWD) of organic matter}

The seawater effluent after each pre-treatment was subjected to MWD measurement to investigate seawater organic matter (SWOM) removal. High pressure size exclusion chromatography (HPSEC, Shimadzu Corp., Japan) with a SEC column (Protein-pak 125, Waters Milford, USA) was used to determine the MW distributions of SWOM (Figure 3). Standards of MW of various polystyrene sulfonates (PSS: 210, 1800, 4600, 8000, and 18000 daltons) were used to calibrate the equipment. The weight-averaged molecular weight can be calculated from the following equation,

$$
M_{w}=\sum_{i=1}^{n}\left(N_{i} M_{i}^{2}\right) / \sum_{i=1}^{n}\left(N_{i} M_{i}\right)
$$

Equation

Where $\mathrm{N}_{\mathrm{i}}$ is the number of molecules having a $\mathrm{MW}$ of $\mathrm{M}_{\mathrm{i}}$ and $\mathrm{i}$ is an incrementing index over all MW present.

\subsection{Membranes and Flux decline experiments}

MF membrane of $0.45 \mu \mathrm{m}$ (cellulose acetate, Whatman GM) is used in the membrane filtration experiments. The pure water permeability of membrane was initially measured.

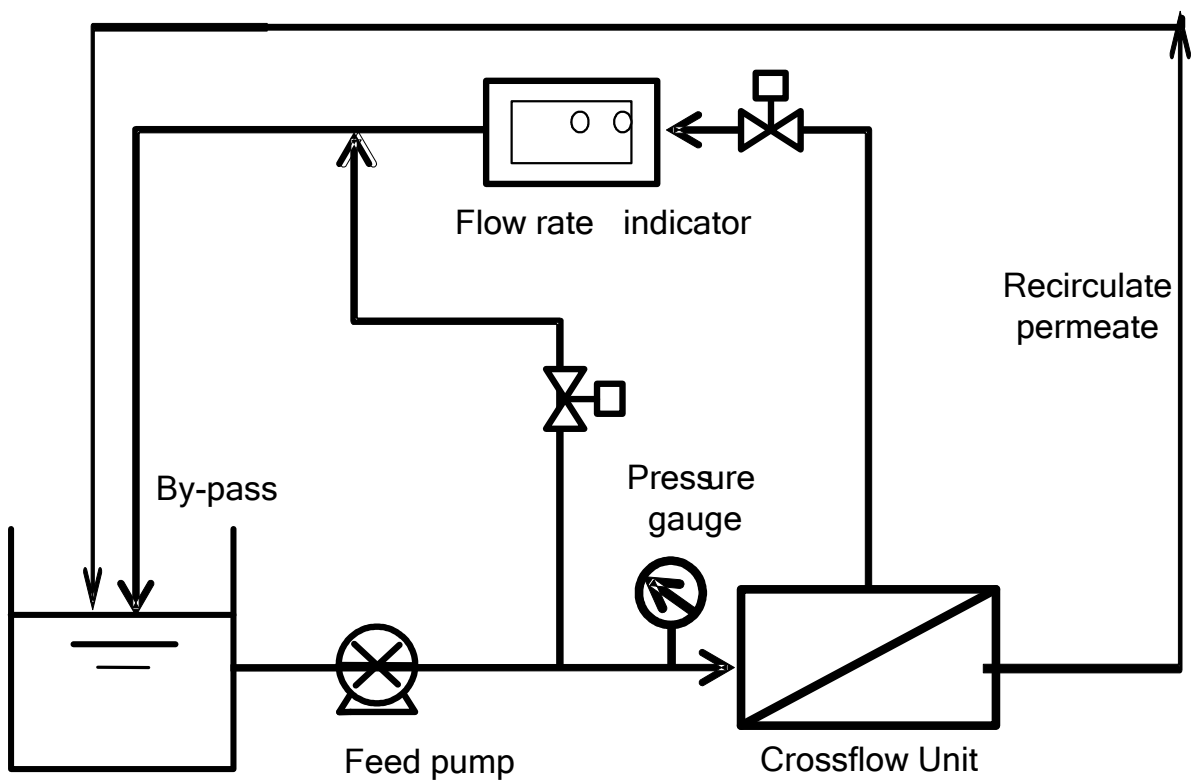

Fig 1: Schematic drawing of cross flow unit

A cross flow sample cell was employed to determine the flux decline test. A $10 \mathrm{~L}$ feed reservoir was employed to provide a continuous supply of feed water, with a pressure of 60 $\mathrm{kPa}$. The cross flow velocity was maintained at $0.5 \mathrm{~m} / \mathrm{s}$. The permeate was recirculated to the feed. Milli- Q water was filtered initially to stabilize the membrane. Pure water flux was 
monitored until a constant flux was obtained. The feed water was then used in the filtration unit to determine the flux decline.

\section{Results and discussion}

\subsection{Flux decline}

The flux decline of MF for pretreated seawater was studied in terms of normalized permeate flux $\left(\mathrm{J} / \mathrm{J}_{0}\right)$. The flux decline $\left(\mathrm{J} / \mathrm{J}_{0}\right)$ for seawater after $3 \mathrm{hrs}$ of MF operation was $45 \%$ (Figure 2). After a pretreatment of deep bed filtration where dual media filtration was used (sand and anthracite, media height of $80 \mathrm{~cm})$ with a dose of $\mathrm{FeCl}_{3}(1 \mathrm{mg} / \mathrm{L})$, the flux decline of MF reduced to about $22 \%$. Filtration with sand (with $\mathrm{FeCl}_{3}$ at a dose of $1 \mathrm{mg} / \mathrm{L}$ ) gave a similar flux decline of $24 \%$. The flux decline with a pre-treatment of $\mathrm{FeCl}_{3}(1 \mathrm{mg} / \mathrm{L})$ alone was $42 \%$. These results indicate that deep bed filtration combined with a low dose of flocculant addition can remove a majority of SWOM. On the other hand, flocculation alone is not sufficient to remove SWOM and requires a subsequent solid liquid separation step.

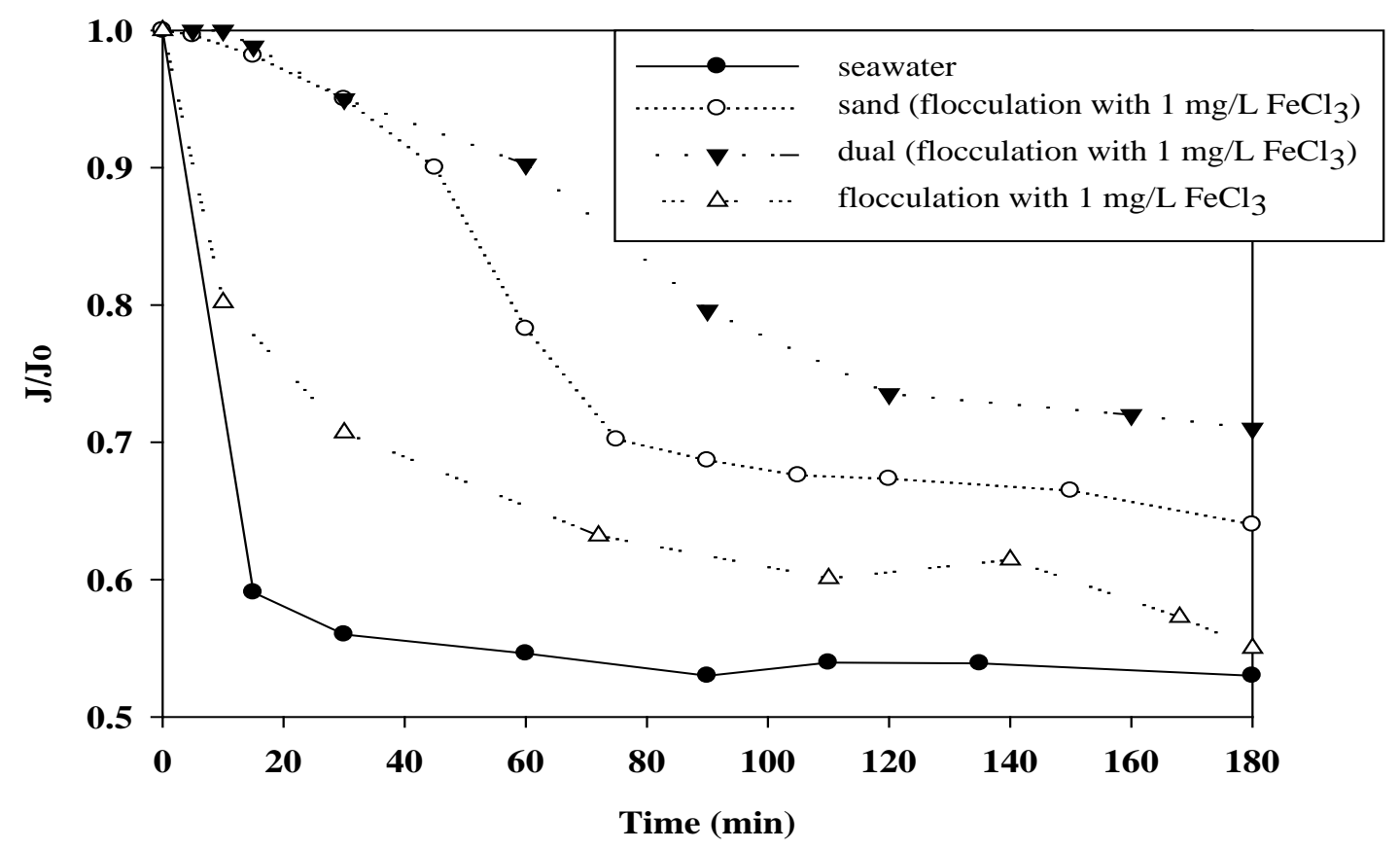

Fig 2: Variation of flux for seawater with and without of pre-treatment

\subsection{Turbidity removal and Molecular weight distribution (MWD)}

Turbidity of initial seawater varied from 0.5 to 0.7 NTU. All pre-treatments used in this study lowered the turbidity to a value of 0.2-0.3 NTU except the case of flocculation with $\mathrm{FeCl}_{3}$. Turbidity of the feed water increased to $1.31 \mathrm{NTU}$ after the addition of $\mathrm{FeCl}_{3}$.

The MWD of SWOM in seawater was measured after each pre-treatment. The MW of the untreated seawater ranged from about 1510 Da to 130 Da. Typical MW peaks for the seawater 
was found at around $1510 \mathrm{Da}, 1180 \mathrm{Da}, 530$ and $130 \mathrm{Da}$ (Figure 3).

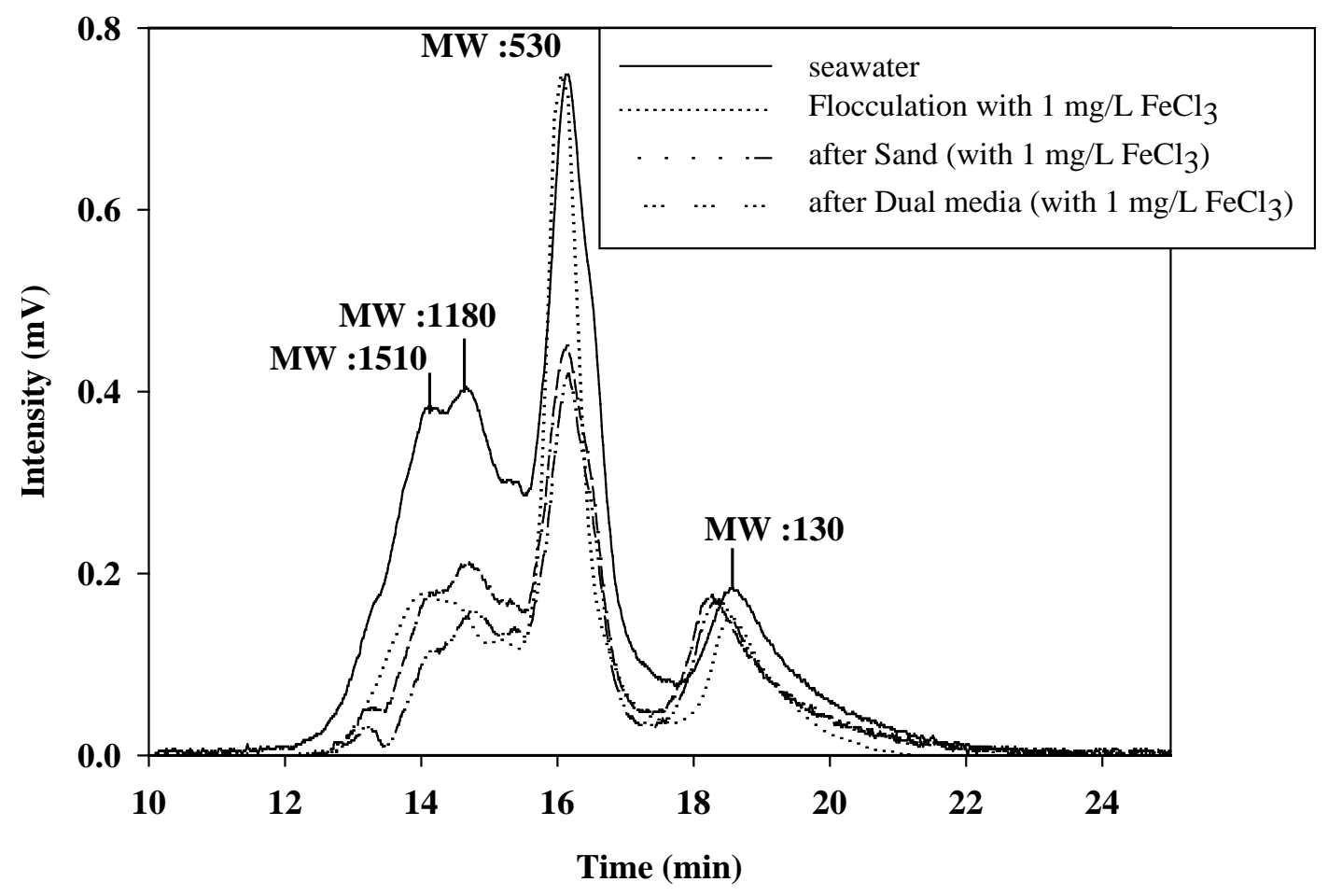

Fig 3: MW distribution of SWOM (seawater organic matter) of seawater and with pre-treated seawater

The MW fraction of $1510 \mathrm{Da}, 1180 \mathrm{Da}, 530$ and $130 \mathrm{Da}$ found in this study represents biopolymers (polysaccharides and proteins), fulvic acid, low MW acids (hydrolysates of humic substances), and amphiphilics, respectively [7, 8]. Fig 3 shows the MWD of SWOM with and without pre-treatment. All pre-treatments used in this study removed polysaccharides type organic compounds that are responsible for membrane fouling [7]. In this study, flocculation with $1 \mathrm{mg} / \mathrm{L} \mathrm{FeCl}_{3}$ removed the majority of large MW SWOM (15101180 daltons) as observed by Shon et.al [9] for wastewater. However, flocculation could not remove the small range MW (530-130) daltons. Furthermore, deep bed filtration with inline coagulation removed both the large (1510-1180 daltons) and the majority of small MW compounds (530 daltons).

\subsection{Effect of pre-treatment}

Different pre-treatments were compared in terms of fouling potential. MFI and $\mathrm{SDI}_{15}$ were measured to access the pre-treatment efficiency in terms of fouling reduction. MFI and SDI 15 was measured using dead end cell. The MFI and $\mathrm{SDI}_{15}$ of raw seawater were $214-256 \mathrm{~s} / \mathrm{L}^{2}$ and 5.8, respectively. After pre-treatment with $\mathrm{FeCl}_{3}$ (of $1 \mathrm{mg} / \mathrm{l}$ ) the MFI was high at $455 \mathrm{~s} / \mathrm{L}^{2}$. A pre-treatment with sand and dual media filtration together with flocculation with $1 \mathrm{mg} / \mathrm{I} \mathrm{FeCl}_{3}$ gave a very low MFI and $\mathrm{SDI}_{15}$ value of $1-2 \mathrm{~s} / \mathrm{l}^{2}$ and 1.9-2 respectively. MF alone as a pretreatment reduced the MFI up to $2.6 \mathrm{~s} / \mathrm{L}^{2}$.

The weight average MWD and the corresponding values after different pre-treatment are shown in Table 2. The weight average MW for seawater was 1420 Da. After the combined 
pre-treatment (that is combination of deep bed filtration with in-line flocculation) MW value decreased. The weight average MWD for sand and dual (with $1 \mathrm{mg} / \mathrm{L} \mathrm{FeCl}_{3}$ ) were 1270 and $1160 \mathrm{Da}$. Both deep bed filtration removed the majority of larger SWOM and leaving only small weight average MW (130 daltons) as shown in Figure 3 and Table 2. As a result the flux decline was also not significant for both media filtration with flocculation (Figure 2). The lowest MFI and $\mathrm{SDI}_{15}$ value for deep bed filtration is also consistent with the lower weight average $\mathrm{MW}$ values. MFI and $\mathrm{SDI}_{15}$ value showed linear result with the weight average $\mathrm{MW}$ values except for $\mathrm{FeCl}_{3}$ flocculation. This result indicates that flocculation alone is not sufficient as a pre-treatment for seawater desalination.

Table 2: comparison of different pre-treatment methods

\begin{tabular}{|l|c|c|c|c|}
\hline Types of feed water & $\begin{array}{c}\text { Weight- } \\
\text { averaged MW } \\
\text { (Da) }\end{array}$ & $\begin{array}{c}\text { MFI } \\
\left(\mathbf{s} / \mathbf{L}^{\mathbf{2}}\right)\end{array}$ & SDI $\mathbf{1 5}^{\text {Flux }}$ & $\begin{array}{c}\text { decline } \\
\text { (\%) }\end{array}$ \\
\hline Seawater after MF alone & 1420 & $\begin{array}{c}214 \\
- \\
256\end{array}$ & 5.8 & 45 \\
\hline Flocculation (with 1mg/l FeCl 3 ) & 1310 & 455 & 6.2 & 42 \\
\hline $\begin{array}{l}\text { Effluent from sand filter with 1 mg/l } \\
\text { FeCl }{ }_{3} \text { flocculation }\end{array}$ & 1270 & 1.8 & 2 & 24 \\
\hline $\begin{array}{l}\text { Effluent from dual media } \\
\text { (sand+anthracite) with } 1 \mathrm{mg} / \mathrm{FeCl}_{3} \\
\text { flocculation }\end{array}$ & 1160 & $<1$ & 1.9 & 22 \\
\hline
\end{tabular}

\section{Conclusions}

The effectiveness of pre-treatment of sand and dual media filtration was evaluated to MF in terms flux decline, MFI, SDI 15 , and MWD. The following conclusions were obtained:

1. Dual media filtration with in-line coagulation gave the lowest value of MFI and $\mathrm{SDI}_{15}$.

2. Flocculation with $1 \mathrm{mg} / \mathrm{L} \mathrm{FeCl}_{3}$ removed relatively large $\mathrm{MW}$ such as $1510 \mathrm{Da}$ and $1180 \mathrm{Da}$ while the relatively small MW that was $530 \mathrm{Da}$ and 130 Da could not be removed. Deep bed media filtration with inline coagulation gave better removal of SWOM (1510 Da- 530 Da).

3. The flux decline in MF indicated the lowest with pre-treatment of dual media filtration with in-line coagulation. Sand filtration with in-line coagulation also gave similar flux decline.

This result indicates that the combination of deep bed filtration (either sand or dual) with flocculation is an attractive pre-treatment to MF for desalination. 


\section{Acknowledgements}

This study was supported by ARC Discovery Project and UTS internal grant.

\section{References}

[1] Wolf, P.H., S. Siverns, and S. Monti, Desalination, 2005. 182(1-3): p. 293-300.

[2] Brehant, A., V. Bonnelye, and M. Perez, Desalination, 2002. 144(1-3): p. 353-360.

[3] Pearce, G.K., Desalination, 2008. 222(1-3): p. 66-73.

[4] Schippers, J.C. and J. Verdouw, Desalination, 1980. 32: p. 137-148.

[5] Schippers, J.C., J. H. Hanemaayer, C. A. Smolders, A. Kostense, Desalination, 1981. 38: p. 339-348.

[6] Boerlage, S.F.E., Maria D. Kennedy, Meseret Petros Aniye, Elhadi M. Abogrean, Gilbert Galjaard, Jan C. Schippers Desalination, 1998. 118(1-3): p. 131-142.

[7] Huber, S.A., Desalination, 1998. 119(1-3): p. 229-234.

[8] Shon, H.K., S. Vigneswaran, and J. Cho, Journal of Membrane Science, 2008. 320(12): p. 151-158.

[9] Shon, H.K., S. Vigneswaran, H.H. Ngo, R. Ben Aim, Water Research, 2005. 39(1): p. 147-153. 